represented the first stage in the proof of the correctness of the $C_{2}$ structure proposed for insulin ${ }^{6}$. Fig. $2 a$ indicates the size and orientation of the molecules in the insulin lattice, deduced from the vector diagram, Fig. $2 b$.

Again, Figs. $l a$ and $b$ show how it proved possible? to deduce from the vector section, $z=\frac{1}{2}^{10}$, the presence and position of three 'foreign' high intensity points per molecule in the lattice, nothing whatever being assumed about the chemical composition of the crystal. The images in Fig. $1 b$ around the cell corners and around the middle point of the cell of the original distribution around the corners of the cell in Fig. la show how the existence and size of the negative intensity region at the centre of the insulin molecule was also deduced from this section? ${ }^{2}$. These investigations, showing that it is possible to deduce that the insulin molecule is a polyhedral cage structure of the shape and size predicted, give some indication of the powerful weapon which the geometrical method puts at our disposal.

${ }^{1}$ Patterson, Phys. Rev., 46, 372 (1934); Z. Krist., 90, 517 (1935).

${ }^{2}$ Harker, J., Chem. Phys., 4, 381 (1936).

3 Llewellyn, Cox and Goodwin, J. Chem. Soc., 883 (1937).

- Crowfoot, Proc. Roy. Soc., A, 164, 580 (1938).

${ }^{5}$ Wrinch, Science, 85, 566 (1937); Trans. Faraday Soc., 33, 1369 (1937).

6 Wrinch, Science, 88, 148 (1938).

? Wrinch and Langmuir, J. Amer. Chem. Soc., in the Press.

${ }^{8}$ Bernal, Réunion Internationale de Physique, Chimie et Biologie, Paris, $407,1937$.

- Crowfoot, loc. cit., Fig. 1.

${ }^{10}$ Crowfoot, loc. cit., Fig. 3.

\title{
Marine Research in the Antarctic
}

$\mathrm{T}$ HE wide scope of the investigations undertaken by the Discovery Committee in the Antarctic is well shown by the contents of their most recent reports ${ }^{1}$. First comes an account of the hydrology of the Southern Ocean by G. E. R. Deacon, which includes two results fundamental to an understanding of world water movements.

Of recent years the origin of the ubiquitous Antarctic bottom water, which in the Atlantic reaches as far as $40^{\circ} \mathrm{N}$., has stimulated oceanographers.

warm deep layer-now shown to exist throughout the whole of the Antarctic Zone--and the resultant highly saline bottom water flows northwards in the Atlantic, Indian and Pacific Oceans. It is the heaviest water in the sea.

On all sides of the Pole, Antarctic surface water also spreads northwards in a shallow surface layer until it reaches the Antarctic convergence. There it plunges abruptly to a deeper level to continue its course as the Antarctic intermediate current. The sharpness and constancy of position of the convergence is now shown to be governed by the movements of the warm deep water and the Antaretic bottom water. The northward movement of the latter depends on the configura. tion of the bottom. The sections at the end of the report suggest that near the convergence the bot. tom water is flowing steeply downhill to the ocean abyss. As to whether this is always so the text is not very clear. At any rate, where the southward moving deep water is opposed by a large volume of Antarctic bottom water, the former is forced up from below 2,000 metres to within 200 metres of the surface. Over this ascending warm deep water, the northward moving Antarctic surface water flows like a cascade to become the Antarctic intermediate current. Room is then left above for the warmer and lighter sub-Antaretic surface water. This picture appears to apply not only to the South Atlantic but also to the Indian and South Pacific Oceans as well. From Discovery Reports, vol. 15.

As a result of the 1932-33 circumpolar cruise of Discovery $I I$, we can no longer suppose that this bottom water is formed by the sinking of shelf water all round the Antarctic Continent. Deacon now believes it to arise in, and only in, the southwestern and western parts of the Weddell Sea. While moving eastwards, it incorporates water from the
There follows an account by A. W. B. Powell on marine mollusca from New Zealand waters, describing six new genera, 128 new species and thirteen genera previously unknown there.

Of the problems in the Antarctic requiring scientific study, perhaps the most urgent is the effect on the stock of Blue whales of modern intensive whaling 
methods. A. H. Laurie finds that Blue whales reach physical maturity at ten or eleven years of age and that they breed only once in two years at most and often only every third year. The length of female Blue whales has decreased so much that on an average they are caught before they have had time to reproduce at all. Continued fishing on the present scale must have a disastrous effect on the stock. As Laurie points out, when killing has reached the point at which recruitment shall virtually have ceased, the future of Blue whales and whaling will be limited to the lifetime of those whales now living. Shall it be said of whaling as may now be said of other branches of the fishing industry: inopem me copia fecit?

1 Discovery Reports, vol. 15. Title page and Contents. Pp. vi. $9 d$. net. The Hydrology of the Southern Ocean. By G. E. R. Deacon. Pp. $124+44$ plates. $30 s$. net. Notes on the Dynamics of the Southern Ocean. By G. E. R. Deacon. Pp. 125-152. 48. net. New Species of Marine Mollusca from New Zealand. By A. W. B. Powell. Pp. 153-222 + plates 45-56. 15s. net. The Age of Female Blue Whales and the Effect of Whaling on the Stock. By A. H. Laurie. Pp. 223-284. 9s. net. (Cambridge: University Press, 1937.)

\section{Progress in Building Research}

A MATTER of considerable importance dealt with in the report for the year 1937 of the Building Research Board, by Dr. R. E. Stradling, director, is the account of the work done in connexion with "Soil Mechanics". This is a new and rapidly developing branch of engineering science which, it is felt, has not received from practising engineers in Great Britain the measure of recognition accorded to it elsewhere. The report therefore lays especial stress on the importance of recent developments in this direction. In the past, it is pointed out, such civil engineering problems as those associated with foundations and the stability of cuttings and embankments, have had to be dealt with on an empirical basis. As the necessary scientific knowledge did not exist this was inevitable ; but a new school of thought has arisen and, following the lines explored by Terzaghi and others, the Station has been engaged in a programme of research. In this it has been actively assisted by the Earth Pressures Committee of the British Association, and by an Earth Pressures SubCommittee set up by the Institution of Civil Engineers. Abroad, the results of research have had a large measure of application and there are reported to be signs of increasing attention here, the inquiries received at the Building Research Station being taken to show that engineers are becoming more fully aware of the assistance which this new science can give in promoting accurate and economical design. This increased interest has had the result that the soil mechanics section at the Station has been strengthened and it is hoped, with the support of outside bodies interested in its aims, to extend its operations and so to hasten the work of fundamental research and the solution of problems of immediate practical interest.

The two avenues of soil research which have been mainly followed at the Station are in connexion with the settlement of structures and the stability of earth slopes. In its method of dealing with the former the development of this science has led to a complete change in the mode of approach to this type of problem. In the past, it was held that the type of soil alone governed the pressure which could be imposed upon it. From the accumulation of practical experience, certain broad rules were evolved and, as a result, the so-called 'bearing values' of different soil types were embodied in tables which formed the basis of design. In difficult or doubtful cases loading tests might be carried out, usually on comparatively small areas, in an endeavour to assess the bearing value in these cases.

The new mode of approach is through an under. standing of the mechanism by which settlements take place and, considering the structure itself, the relative amount of settlement permissible as between one part of the structure and another is regarded as the determining factor in the design of the foundations. It is to the work of Terzaghi and his followers that an appreciation of the broad aspects of the problem is due. Although, as the report states, the mechanism by which settlements occur has not as yet been fully explained, it is understood that settlement depends not only on the type of soil immediately below the footings but also on the nature of the soil strata to a considerable depth. A deep-seated stratum of soft clay may be, and indeed has often been, the cause of serious settlement. Apart from the influence of the pressure on a footing, settlement depends on the size of the footing, the depth at which it is placed and the presence of other footings in the immediate proximity. In the case of clay soils, time is also an important element, for settlement continues at a diminishing rate for a period determined by the conditions, and failure may occur some time after the completion of the structure. With so many factors entering into the problem, the difficulty in interpreting the results of loading tests and in appraising the limitations associated with them becomes obvious.

In the second part of the report, which contains the more detailed account of the Station's activities during the year, an outline is given of the methods employed in estimating and analysing the settlement of a structure. It is based on the laboratory examination of soil samples taken in an 'undisturbed' condition from several strata beneath the structure. From the results of tests made with the Terzaghi oedometer together with calculation of the distribution of pressure from the building, it is possible to estimate the amount of settlement to be expected. It may be objected that the conditions of the test do not actually reproduce those existing in practice, and this is acknowledged, but if, from actual measurements, agreement can be shown between the actual and the estimated movements, then a very great step forward can be recorded. This represents the present stage of development of the subject; every effort is being made to get information about such comparisons and, the more the work progresses, the more impressive does the closeness of the correlation appear. The results of work done in connexion with a new building for the Fire Testing Station, Elstree, will shortly be published and it is claimed that the agreement in this case is as near as one can hope to get. Further cases are under observation and, as the data from these become available, this method of testing and 